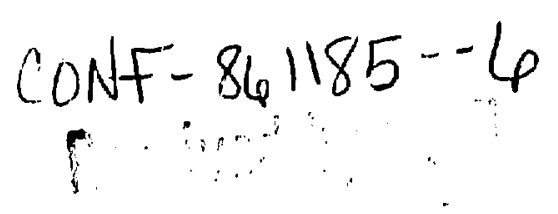

CONF-861185--6

DE87 004752

\title{
PRELIMINARY LEU FUEL CYCLE ANALYSES \\ POR THE BELGIAN BR2 REACTOR
}

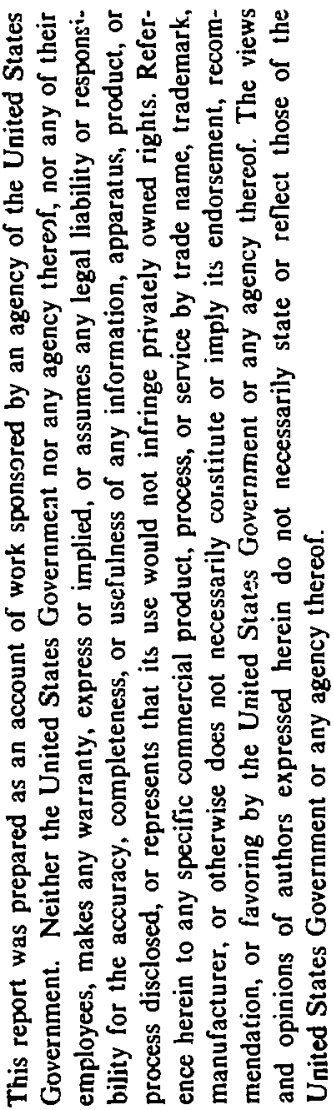

J. R. Deen and J. L. Snelgrove

Argonne National Laboratory

Argonne, Ill1nols, U.S.A.

To be Presented at the

International Meeting

on

Reduced Enrichment for

Research and Test Reactors (RERTR)

November 3-6, 1986

Gatlinburg, Tennessee

\begin{abstract}
The wbmitted manuxcript has been wuthored by a contractor of the U.S. Government under contrect No. W-31-109ENG-38. Accordinglv, the U.S. Government retrins nonekclusive, rovalty-free license to publith or noproduce the published form of this contribution, or sllow others to do $\infty$, for U. S. Governnent purposes.
\end{abstract}

*Work performed under the ausplces of the U.S. Department of Energy 
PRELIMINARY LEU FUEL CYCLE ANALYSES FOR THE GELGIAN BR2 REACTOR

\author{
J. R. Deen and J. L. Snelgrove \\ Argonne National Laboratory \\ Argonne, Illinols USA
}

\begin{abstract}
Fuel cycle calculations have been performed with reference HEU fuel and LEU fuel using Cd wires or boron as burnable absorbers. The ${ }^{235} \mathrm{U}$ content in the LEU element has Increased $20 \%$ to $480 \mathrm{~g}$ compared to the reference HEU element. The number of fuel plates has remalned unchanged while the fuel meat thickness has increased to $0.76 \mathrm{~mm}$ from $0.51 \mathrm{~mm}$. The LEU meat density is $5.1 \mathrm{U} / \mathrm{m}^{3}$. The reference fuel cycle was a 31 element core operating at $56 \mathrm{MW}$ with a 19.8 day cycle length and elght fresh elements loaded per cycle. Comparable fuel cycle characteristics can be achleved using the proposed LEU fuel element with elther Cd wires or boron burnable absorbers. The neutron flux for $E_{n}$ $>1 \mathrm{eV}$ changes very little $(\langle 5 \%)$ in LEU relative to HEU cores. Thermal flux reductions are 5 to $10 \%$ in non-fueled positions, and 20 to $30 \%$ in fuel elements.
\end{abstract}

\title{
INTRODUCTION
}

The Reduced Enrlchment Research and Test Reactor (RERTR) Program and the Centre d'Etude de 1'Energy Nucléalre (CEN/SCK) have been engaged in a joint study to determine the most sultable LEU fuel element design for the BR2 react or In Mol, Belgium. This paper presente results obtained to date from neutronics and fuel cycle calculations. A complete description of the current HEU core and fuel cycle was presented at the 1984 annual meeting.

In the early stages of the search for an optimal LEU fuel element a single-element, exact-geometry viM-Monte Carlo ${ }^{2}$ model was used to determine the reactivity and power peaking effects of changing the number of fuel plates and burnable absorber content and location. It was clear from the beginning that an increase in the fuel meat thickness would be needed because an LEU meat density of $7.3 \mathrm{Mg} \mathrm{U} / \mathrm{m}^{3}$ would be required if the HEU element geometry were unchanged. The simplest approach to the meat volume increase, preserving the number of fuel plates and increasing the meat thlckness from 0.51 mm to 0.76 $\mathrm{mm}$, has been adopted for fuel cycle design studies. This modification achieves a $20 \%$ increase in the ${ }^{235} \mathrm{U}$ content of the LEU element relative to the reference HEU element with a fuel meat uranium density of only $4.9 \mathrm{Mg} / \mathrm{m}^{3}$. Thermal-hydraulic analyses performed by the BR2 staff ${ }^{3}$ indicate some reduction In maximum allowable power density resulting from the reduction in coolant flow area owling to the use of thlcker fuel plates. 
The development and results of the fuel cycle models for HEU and LEU fuels with boron or Cd wire burnable absorbers are presented in this paper. In the core model all holes in the Be matrix are filled th either fuel, control rods or Be plugs. Three-dimensional hexagonal geometry equilibrium fuel cycle results with partially inserted control rods banked at fixed positions were used for final comparisons of HEU and LEU performance characteristics. Fuel cycle studies were performed with configuration 10D, having 31 elements, operating at a power level of $56 \mathrm{MW}$ and $67.2 \mathrm{MW}$.

VIM-MONTE CARLO CALCULATIONS FOR FUEL ELEMENT MODEL DEVELOPMENT

\section{Fuel Description}

The fuel element has six concentric fuel rings with a central Al-clad Be plug which can be replaced with irradiation rigs. The fuel zone is surrounded by hexagonal Be matrix blocks. Each fuel ring is formed by three fuel plates secured in position in the element by mechanical connection along their edges to three equally spaced radial Al webs (corresponding to the side plates of box-type elements). The webs extend from the inner Al ring surrounding the central Al- clad Be plug to the Inner surface of the Be matrix block. See Fig. 1 for a complete description of the reference HEU fuel element.

\section{VIM Model}

For determination of changes in $k_{\infty}$ and power shape, a 1/6-element VIM model of the reference HEU element and several proposed LEU elements was developed. The VIM model is an exact geometrical description of the location of each fuel plate, Be plug and matrix block and water channel. The outer fuel plate was divided into several separate tally regions in order to obtain information regarding the power peaking in this most limiting zone. (Average fluxes and reaction rates are computed for each tally region.) Each of the inner plates was divided into successively fewer tally regions to gain additional detalls about the power shape within the element. other tally regions were devoted to obtalning flux and reaction rate changes observed in other zones of the element such as the moderator, central Be plug, Be matrix block, web, and Cd wires when present. The fuel elements were modelcd using zero current boundary conditions so that the results are indicative of an infinite medium of identical fuel elements. The results of the singleelement, fresh-fuel VIM cases for various fuel element designs are presented in Tables 1 or 2 .

\section{VIM Results for HEU Fuel}

The first case presented in Table 1 is the reference HEU fuel element with boron and samarium burnable absorbers homogeneously mixed into the fuel meat. The peak power clensity occurs at the end of the outer fuel plate close to the $A$ zeb structure. The second case is identical to the reference case except for the removal. of all boron and samarium from the fuel meat. The third and fourth HEU calses presented in Table 1 illustrate the effect on 
Figure 1. Description of Reference HEU Element

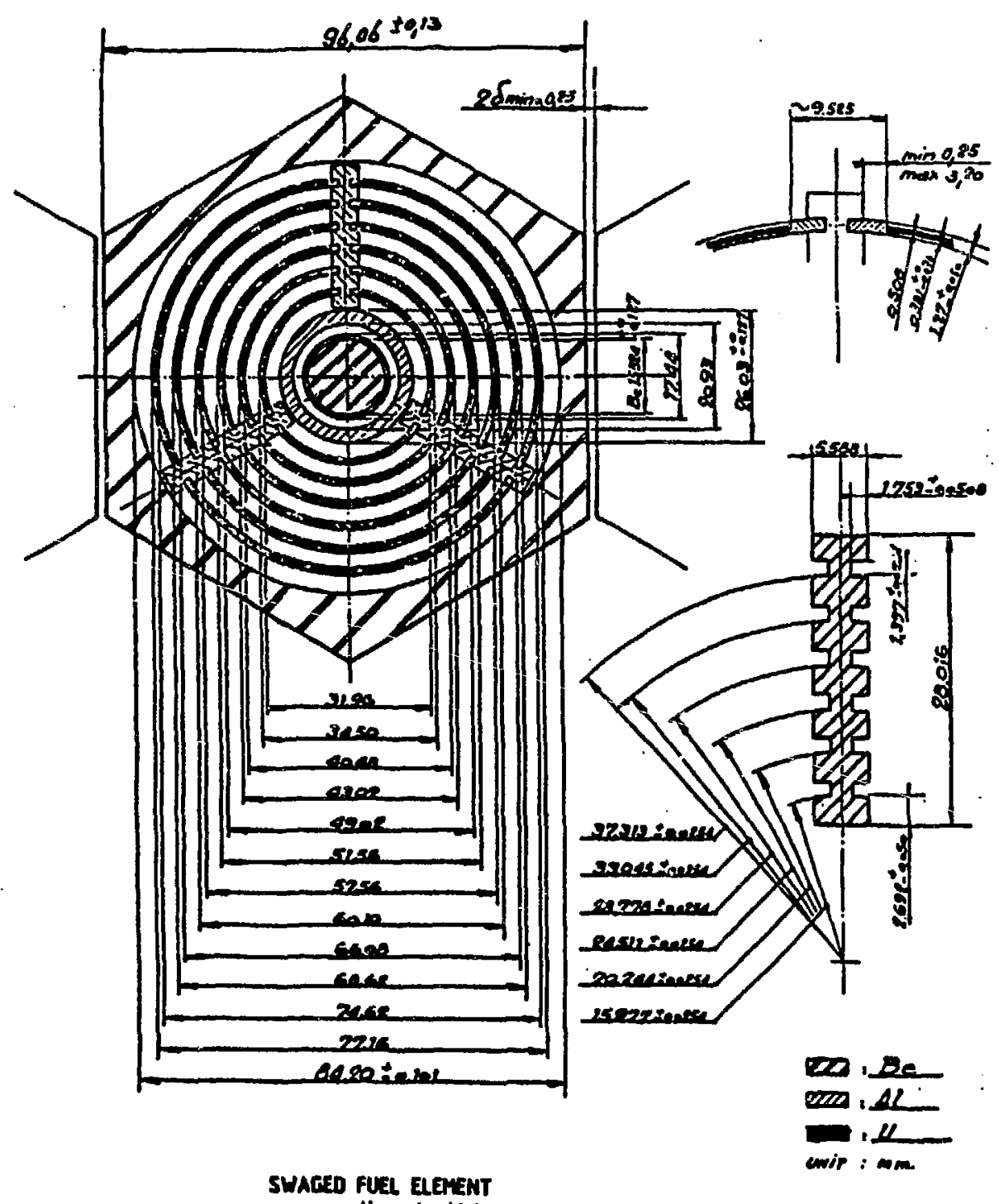

Figure 2. Placement of Cd W1res in LEO Fuel Element

I. Nere ca Hire Rlecenoes

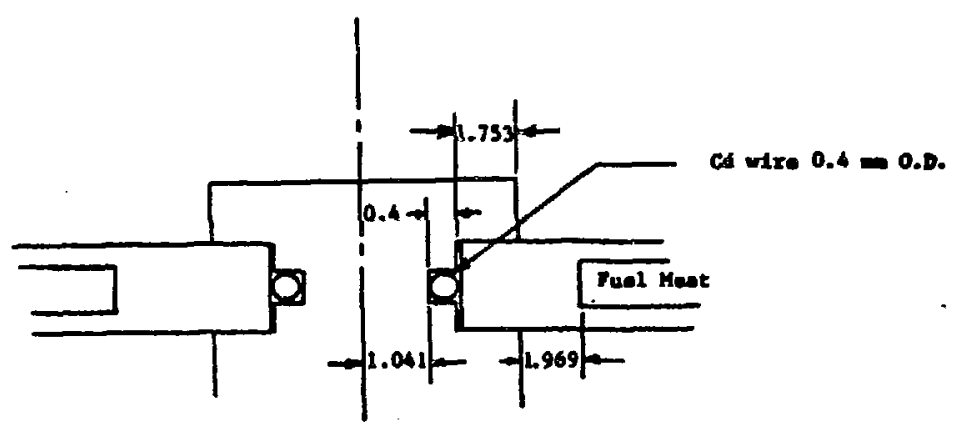

II. Gad a viro Rlaement

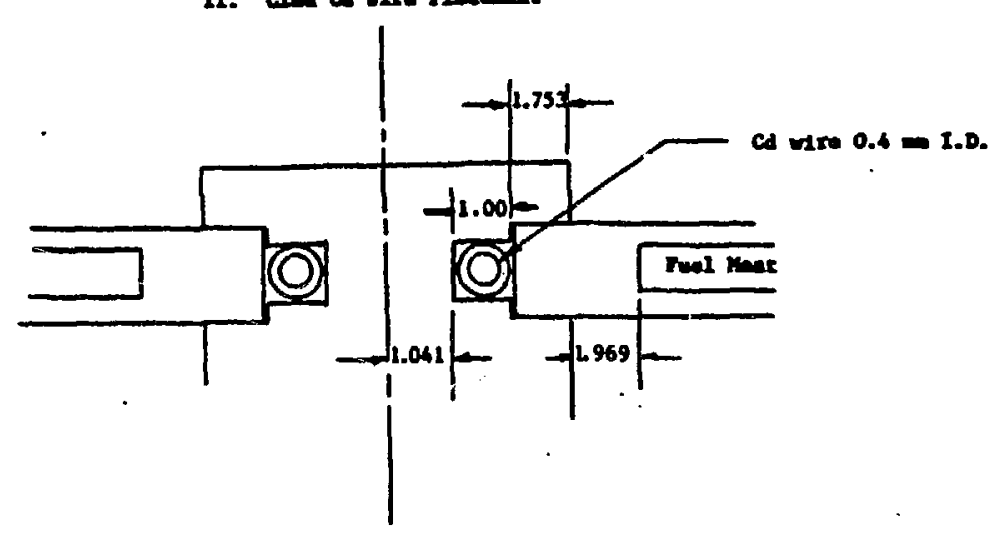

notos All dimanion in $m$. 
Table 1. Summary of Peaking Factor and Reactivity for Varlous BR2 Fuel Element Designs Using VIM-Monte Carlo (Equal Water Channels Between All FueI Plates and Be Matr $1 x$ Block for LEU Elements)

\begin{tabular}{|c|c|c|c|c|c|c|c|c|c|c|}
\hline $\begin{array}{l}\text { Puel Type } \\
\text { and } \\
23 S_{\mathrm{U}-\mathrm{g} / \mathrm{el}}\end{array}$ & $\begin{array}{l}\text { Burnable } \\
\text { Absorber } \\
\text { B/So(B) }\end{array}$ & $\begin{array}{l}\text { BA } \\
\text { Location } \\
\text { and } \\
\text { Dimensions } \\
(\operatorname{mos} x)\end{array}$ & $\begin{array}{l}\text { Water } \\
\text { Channel } \\
\text { Thickness } \\
\text { (am) }\end{array}$ & $\begin{array}{l}\text { Moderator } \\
\text { Volung } \\
\text { Change } \\
(x)\end{array}$ & $\begin{array}{l}\text { Plates/ } \\
\text { Element }\end{array}$ & $\begin{array}{c}\text { Meat } \\
\text { Thicknes } \\
\text { (mm) }\end{array}$ & $k$ & $\begin{array}{l}\text { Power } \\
\text { Peaking } \\
\text { Factor } \\
\end{array}$ & $\begin{array}{l}\text { Meat } \\
\text { Volume } \\
\left(\mathrm{cm}^{3}\right) \\
\end{array}$ & $\left(\mathrm{g} / \mathrm{cn}^{3}\right)$ \\
\hline HEU -400 & $3.8 / 1.4$ & Meat & 3.0 & 0.0 & 6 & 0.508 & 1.3858 & 1.22 & 331.7 & 1.30 \\
\hline HEU -400 & $0.0 / 0.0$ & - & 3.0 & 0.0 & 6 & 0.508 & 1.8061 & 1.19 & 331.7 & 1.30 \\
\hline HEU -400 & $3.8 / 1.4$ & $\begin{array}{c}\text { Heb } \\
(11 \times 1)\end{array}$ & 3.0 & 0.0 & 6 & 0.508 & 1.5562 & 1.13 & 331.7 & 1.30 \\
\hline HEU -400 & $7.6 / 1.4$ & $(11 \times 1)$ & 3.0 & 0.0 & 6 & 0.508 & 1.4940 & 1.15 & 331.7 & 1.30 \\
\hline LEU -480 & $3.8 / 1.4$ & Meat & 3.0 & 0.0 & 6 & 0.508 & 1.3668 & 1.22 & 331.7 & 7.33 \\
\hline LEU -480 & $0.0 / 0.0$ & - & 3.0 & 0.0 & 6 & 0.508 & 1.7170 & 1.19 & 331.7 & 7.33 \\
\hline LEU -480 & $3.8 / 1.4$ & $\left(\begin{array}{c}\text { Web } \\
(1 \times 1)\end{array}\right.$ & 3.0 & 0.0 & 6 & 0.508 & 1.4985 & 1.14 & 331.7 & 7.33 \\
\hline LEU $-\mathbf{6 8 0}$ & $3.8 / 1.4$ & $\begin{array}{c}\text { Web } \\
(25 \times 1)\end{array}$ & 3.0 & 0.0 & 6 & 0.508 & 1.4480 & 1.16 & 331.7 & 7.33 \\
\hline LEU-480 & $3.8 / 1.4$ & Meat & 2.85 & -7.8 & 6 & 0.760 & 1.3769 & 1.24 & 502.3 & 4.84 \\
\hline LEC -480 & $3.8 / 1.4$ & Meat & 3.58 & 0.0 & 5 & 0.760 & 1.3757 & 1.22 & 418.7 & 5.81 \\
\hline$L E U-680$ & $3.8 / 1.4$ & Meat & 3.38 & -6.4 & 5 & 1.000 & 1.3700 & 1.19 & 550.8 & 4.41 \\
\hline LEU-480 & $3.8 / 1.4$ & $\begin{array}{l}\text { Web/Meat } \\
(11 \times 1)\end{array}$ & 2.85 & -7.8 & 6 & 0.760 & 1.3985 & 1.09 & 502.3 & 4.84 \\
\hline
\end{tabular}

* Half of the burnable absorber 1s located in the s1de plate and the other half is located in the fuel aeat.

Table 2. Infinite Lattice Characteristics for Varicus LEU Six Plate Fuel Elements Using VIM-Monte Carlo

\begin{tabular}{|c|c|c|c|c|c|c|c|c|c|}
\hline \multirow[b]{2}{*}{$\begin{array}{l}\text { Fuel } \\
\text { Type }\end{array}$} & \multicolumn{2}{|c|}{ Burnable Absorber } & \multicolumn{2}{|c|}{ Characteristics } & \multirow{2}{*}{$\begin{array}{c}\begin{array}{c}\text { Meat } \\
\text { Thickness } \\
\text { (mis) }\end{array} \\
\end{array}$} & \multirow{2}{*}{$\begin{array}{l}\text { Meat } \\
\text { Volume } \\
\left(\mathrm{cm}^{3}\right) \\
\end{array}$} & \multirow{2}{*}{$\begin{array}{c}\text { Uraniun } \\
\text { Meat } \\
\text { Density } \\
\left(\mathrm{g} / \mathrm{cm}^{3}\right) \\
\end{array}$} & \multirow{2}{*}{$\begin{array}{l}\text { Power } \\
\text { Peaking } \\
\text { Fact or }\end{array}$} & \multirow[b]{2}{*}{$k_{0}$} \\
\hline & Composition & Location & $\begin{array}{l}\text { Load Ing } \\
(\mathrm{g})\end{array}$ & $\begin{array}{c}\text { Dimens1ons } \\
\text { (m) }\end{array}$ & & & & & \\
\hline LEU -480 & $\mathrm{~B} / \mathrm{Sm}$ & Meat & $3.8 / 1.4$ & In meat & 0.76 & 493.9 & 4.92 & 1.23 & 1.3682 \\
\hline LEU -480 & $-/ S \mathrm{~s}$ & Meat & $0 / 1.4$ & In neat & 0.76 & 493.9 & 4.92 & 1.20 & $1.6015 ?$ \\
\hline LEU -480 & $\mathrm{~B} / \mathrm{S} \pi$ & Web/Meat & $3.8 / 1.4$ & $11 \times 1^{*}$ & 0.76 & 493.9 & 4.92 & 1.14 & 1.4005 \\
\hline LEU -480 . & $\mathrm{Cd} / \mathrm{Sm}$ & Web/Meat & $67 / 1.4$ & $\begin{array}{c}36 \text { bare } \\
(0.6)\end{array}$ & 0.76 & 481.4 & 5.05 & 1.19 & 1.3734 \\
\hline$L E U-480$ & $\mathrm{Cd} / \mathrm{Sm}$ & Web/Meat & $67 / 1.4$ & $\begin{array}{c}36 \underset{(0.6)}{c l a d} \\
(0.6\end{array}$ & 0.76 & 468.9 & 5.18 & 1.19 & 1.3670 \\
\hline LEU-480 & $\mathrm{Cd} / \mathrm{Sm}$ & Heb/Meat & $\begin{array}{r}47 / 1.4 \\
.\end{array}$ & $\begin{array}{c}36 \underset{(0.5)}{c l a d} \\
(0.5)\end{array}$ & 0.76 & 473.0 & 5.14 & 1.17 & 1.4056 \\
\hline LEU-480 & $\mathrm{Cd} / \mathrm{sm}$ & Web/Meat & $30 / 1.4$ & $\begin{array}{c}36 \underset{(0.4)}{\text { clad }} \\
\text { w }\end{array}$ & 0.76 & 473.0 & 5.14 & 1.15 & 1.4385 \\
\hline
\end{tabular}

\footnotetext{
"Dimensions of burnable absorber volume in each veb structure. Half of the burnable absorber materlal is In the web and the other half is in the fuel meat volure.

Note: Hater channel thickness between fuel plates $182.74 \mathrm{~m}$ and $3.52 \mathrm{~mm}$ between outer place and Be $\mathrm{flll}$ (1) block.
} 
element $k_{\infty}$ and power peaking of shifting the burnable absorber from the fuel meat Into the Al web. The location of the power peak has been reduced $7 \%$ and shifted from the edge of the outer plates to the mid-point between the Al webs 1n the outer plates. The concentration of the burnable absorber in the web is dilute enough not to affect the depletion rate of the ${ }^{10} \mathrm{~B}$ or ${ }^{149} \mathrm{Sm}$ compared to the reference HEU fuel.

\section{VIM Reguits for LEU Fuel}

The next set of cases presented in Table 1 uses LEU fuel. The burnable absorber loading and composition has not changed from the HEU reference design but the location is sometimes shifted to the web. The first LEU case represents only a change in the fuel meat composition without any change to the element geometry. The peak-to-average ( $\mathrm{P} / \mathrm{A})$ power density ratio 18 unchanged while the reactivity has been reduced by $\sim 1000 \mathrm{pcm}$. $\left(1 \mathrm{pcm}=10^{5} \times\right.$ $\left.\left(k_{1}-k_{2}\right) / k_{1} k_{2}\right)$. The effects of complete removal of the burnable absorber from the element or of shifting the burnable absorber to the web are noted in the second and third LEU cases. The effect of an increase in the burnable absorber volume in the web upon element reactivity and power peaking can be noted by comparing the third and fourth LEU cases.

The next four LEU cases had fuel plates equally spaced between the Be plug and the Be matrix block. The HEU reference design has a larger channel gap $(3.52 \mathrm{~mm}$ ) between the cuter plate and Inner surface of the Be matrix block than the channel gap $(3.0 \mathrm{~mm})$ between plates. Each LEU design represents a substantial decrease in required fuel meat density without much change in coolant flow area, ${ }^{235} \mathrm{U}$ loading, or element $k_{\infty}$. The lowest uranium density was obtained for the case using five plates with a 1.00-mm-thick meat. This element was not considered feasible chlefly because a reduced coolant volume of $6.4 \%$ was combined with a reduced heat transfer area of $15.8 \%$ with respect to the reference design. The other five-plate design $(0.76 \mathrm{~mm}$ meat thickness), while not having any coolant flow area reduction, did have a $15.6 \%$ reduction in heat transfer area. The optimum element for further study was the six-plate element with $0.76-\mathrm{mm}$-thick meat because it has a uranfum density achievable with $\mathrm{U}_{3} \mathrm{SI}_{2}$ and, compared to the reference $\mathrm{HEU}$ element, no reduction in heat transfer area and only a small reduction in channel gap thickness. The last case in Table 1 shows that power peaking 18 best controlled by distributing the burnable absorber within both the fuel meat and the web.

Presented in Table 2 are the results of VIM studies of several LEU design options using six plates with $0.76-\mathrm{mm}$-thick meat and using either boron or cadmium with samarium as burnable absorbers. Bach of these LEU designs has an outer water channel thickness of $3.52 \mathrm{~mm}$, which is the same as that for the HEU reference design. This results in a 2.74 min water channel between the fuel plates. The slight change in the location of each fuel plate caused a $1.7 \%$ Increase in the required LEU meat density $\left(4.92 \mathrm{~g} / \mathrm{cm}^{3}\right)$. By distributing $50 \%$ of the burnable absorber material in the fuel meat and the other $50 \%$ in a small volume $11 \times 1 \times 762(\mathrm{~mm} \times \mathrm{mm} \times \mathrm{mm})$ in the web, the power peaking factor can be reduced $6.6 \%$ without significant changes in the reactivity of the element. The ${ }^{10} \mathrm{~B}$ depletion rates are very close to the infinite dilution (maximum) rate in both meat and web volumes. 
In the last four LEU cases listed in Table 2 boron has been replaced by bare or Al-clad Cd wires. One Cd wire 1s located at each edge of each of thr: elghteen fuel plates as shown in F1g. 2. Therefore, each Al web contains 12 Cd wires placed in special grnoves cut in the bottom of the normal web grooves so that the wires can be held in position by the fuel plates. The power peaking factor has been reduced by from 2.5 to $5.7 \%$ using $\mathrm{Cd}$ wires. The peak power denifty location has shifted to the point in the outer plates midway between the webs.

DEVELOPMENT OF A FUEL CYCLE MODEL USING DIFFUSION THEORY BENCHMARKED TO VIM

\section{EPRI-CELL Cross Section Generation Model}

The computer code EPRI-CELL 4 (ECELL) uses one-dimensional integral transport theory with 35 neutron groups below $1.85 \mathrm{eV}$ (similar to THERMOS) and 68 neutron groups above $1.85 \mathrm{eV}$ in a homogeneous mixture (similar to GAM). The fine-group cross sections are collapsed into five broad groups. A cylindrical representation of the fuel element was developed in which each fuel meat, clad, and moderator zone was modeled separately. A total of 44 mesh points was required for this model to calculate burnup-dependent cross sections for each lsotope in each fuel plate of the fuel element. For the fuel elements with Cd wires, a separate Cd cross section generation model was developed. The resulting microscopic cross sections were compared with the VIM results and were found to be in reasonable agreement.

Each of the six shim rods in the core required four separate sets of cross sections. The two control zones contained elther Cd or Co as absorbers, one zone consisted of a short axial region of $\mathrm{Al}$ and $\mathrm{H}_{2} \mathrm{O}$ and another zone consisted of a Be follower section. Each of these axial zones of the control rod was represented by a cylindrical model surrounded by an outer zone of homogenized fresh fuel. Only two axial zones were modeled for the two regulating control rods in the core: a Cd control zone and a Be follower zone. A cylindrical model similar to that for the shim rods was used for these two regulating rod zones.

\section{EPRI-CELL Cross Section Model for Depletion of Cd Wires}

The depletion of $c d$ wires in ECELL could not be simulated using the fuel element cross section model because of the wire location and the concentration of absorber material in a very small volume. An ECELL Cd cylindrical model was developed which consisted of four different zones representing the material surrounding a single cd wire. The main criterion for achieving a good ECELL model for cd depletion was to create a neutron spectrum over the entire volume of the wire that would be as close as possible to the spectrum calculated by VIM. This was achieved by adjusting the volume of the fuel and Be zones to provide the proper neutron source to the central wire zone. Once this spectrum was achieved, the ECELL-calculated $\Sigma_{a_{5}}$ of the wire was within
$\pm 1 \%$ of the VIM result, as shown in Table 3 . 
Table 3. Comparison of VIM and ECELI Cd Cross Sections and Neutron Spectra at Various Burnups for $0.4-\mathrm{mm}-O D$ Cd Wires

\begin{tabular}{|c|c|c|c|c|c|c|c|c|}
\hline${ }_{283}^{30 x}$ & (II) & 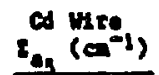 & $\begin{array}{c}\text { aelaetve } \\
1\end{array}$ & $\begin{array}{c}\text { Meucroo } \\
12 \\
\end{array}$ & $\begin{array}{c}\text { Nux } \ln 0 \\
\vdots\end{array}$ & ad Hire & $\begin{array}{c}\text { per sroup } \\
\text { ts }\end{array}$ & \\
\hline 0 & $\begin{array}{l}0 \\
0\end{array}$ & $\begin{array}{l}85.9 \\
86.2\end{array}$ & $\begin{array}{l}0.253 \\
0.251\end{array}$ & $\begin{array}{l}0.354 \\
0.355\end{array}$ & $\begin{array}{l}9.302 \\
0.306\end{array}$ & $\begin{array}{l}0.040 \\
0.030\end{array}$ & $\begin{array}{l}0.050 \\
0.049\end{array}$ & $\begin{array}{l}\text { YIT } \\
\text { ECELL }\end{array}$ \\
\hline $\begin{array}{l}6.91 \\
6.91\end{array}$ & $\begin{array}{l}54.4 \\
54.4\end{array}$ & $\begin{array}{l}38.5 \\
41.5\end{array}$ & $\begin{array}{l}0.242 \\
0.241\end{array}$ & $\begin{array}{l}0.338 \\
0.342\end{array}$ & $\begin{array}{l}0.209 \\
0.295\end{array}$ & $\begin{array}{l}0.038 \\
0.038\end{array}$ & $\begin{array}{l}0.093 \\
0.083\end{array}$ & $\begin{array}{l}\text { YIM } \\
\text { ECELL }\end{array}$ \\
\hline $\begin{array}{l}10.74 \\
10.74\end{array}$ & $\begin{array}{l}78.3 \\
78.3\end{array}$ & $\begin{array}{l}22.4 \\
22.3\end{array}$ & $\begin{array}{l}0.233 \\
0.234\end{array}$ & $\begin{array}{l}0.318 \\
0.331\end{array}$ & $\begin{array}{l}0.281 \\
0.286\end{array}$ & $\begin{array}{l}0.038 \\
0.037\end{array}$ & $\begin{array}{l}0.127 \\
0.112\end{array}$ & $\begin{array}{l}\text { YIM } \\
\text { eCELL }\end{array}$ \\
\hline $\begin{array}{l}15.77 \\
15.77\end{array}$ & $\begin{array}{l}95.7 \\
95.7\end{array}$ & $\begin{array}{l}4.34 \\
5.08\end{array}$ & $\begin{array}{l}0.212 \\
0.222\end{array}$ & $\begin{array}{l}0.299 \\
0.315\end{array}$ & $\begin{array}{l}0.259 \\
0.272\end{array}$ & $\begin{array}{l}0.035 \\
0.036\end{array}$ & $\begin{array}{l}0.196 \\
0.155\end{array}$ & YIM $_{\text {ECEL2 }}$ \\
\hline $\begin{array}{l}25.61 \\
25.61\end{array}$ & $\begin{array}{l}100 \\
100\end{array}$ & $\begin{array}{l}0.05 \\
0.22\end{array}$ & $\begin{array}{l}0.202 \\
0.215\end{array}$ & $\begin{array}{l}0.285 \\
0.305\end{array}$ & $\begin{array}{l}0.247 \\
0.264\end{array}$ & $\begin{array}{l}0.034 \\
0.035\end{array}$ & $\begin{array}{l}0.232 \\
0.181\end{array}$ & $\begin{array}{l}\text { VIM } \\
\text { ECELL }\end{array}$ \\
\hline
\end{tabular}

Neutron Energy Braed Group Boundaries

\begin{tabular}{|c|c|c|}
\hline iroup & $\underline{\varepsilon}_{\text {upper }}$ & Elever \\
\hline 1 & $10.0 \mathrm{MeV}$ & $0.621 \mathrm{keV}$ \\
\hline 2 & 0.821 HeV & $5.53 \mathrm{~K} \in \mathrm{V}$ \\
\hline 3 & $5.53 \mathrm{reV}$ & $1.855 \mathrm{eV}$ \\
\hline 4 & $1.855 \mathrm{eV}$ & $0.625 \mathrm{eV}$ \\
\hline 5 & $0.625 \mathrm{eV}$ & 0.0 \\
\hline
\end{tabular}

Control Rod Benchmark Comparisons Using VIM and DIF3D

The BR2 core conflguration is a non-symmetrical hexagonal array of fuel and reflector elements, control rods, and experiment rigs. Each hexagonal position must be represented by a homogeneous composition in the diffusiontheory DIF3D core model.5 In order to model control elements using a single composition each for the $C d$, Co, or no-absorber planes of a control rod, adjustment of the microscopic thermal cross section of Cd or Co was necessary to properly represent the neutronic effect of the control rod upon the core. The VIM model was used again as a basis for determining the fraction of absorptions occuring in either $C d$ or Co planes of a control element.

In addition to planar VIM/DIF3D comparisons using HEU or LEU fuel, one three dimensional comparison of axial power distribution and reactivity for a partially Inserted control rod in an HEU fresh fuel environment was performed. The calculation consisted of a central control element surrounded by a full ring of six fresh hexagonal fuel elements. The control rod is withdrawn 505 from the fully inserted position. Presented in Table 4 are the results a DIF3D-VIM comparison using coarse axial mesh, identical to the fuel cycle model axial mesh. This comparison gives an indication of the magnitude and direction of the axial power shape differences resulting from using the REBUS 3 fuel cycle model. The differences in reactivity, reaccion rates, and axial power shape are not considered significant for these prellminary fuel cycle analyses. 
Tab1e 4. Benchmark Comparison of VIM and DIF3D Standard-Axia1-Mesh Model of Fission Rate D1stributions with ShIm Control Rod at $505 \mathrm{~mm}$ Surrounded by One Ring of Fresh HEU Fuel

\begin{tabular}{|c|c|c|c|c|}
\hline$\left(\frac{2}{2}\right)$ & $\begin{array}{c}z_{y} \\
(\mathrm{e}) \\
\end{array}$ & $\begin{array}{c}\text { Rolaciv } \\
\text { VIH } \\
\end{array}$ & $\begin{array}{l}\text { T10sion Inte } \\
\text { DIP3D }\end{array}$ & Ideferance \\
\hline 94.96 & 76.2 & 0.0547 & 0.0321 & -4.0 \\
\hline 36.84 & 64.96 & 0.0652 & 0.0834 & -2.0 \\
\hline 48.72 & 56.84 & 0.0954 & 0.0922 & -3.4 \\
\hline 40.60 & 48.72 & 0.1265 & 0.1208 & -3.2 \\
\hline 32.40 & 40.60 & 0.1501 & 0.1469 & -2.1 \\
\hline 24.36 & 32.48 & 0.1563 & 0.1578 & +0.9 \\
\hline 16.24 & 24.36 & 0.1472 & 0.1495 & +1.6 \\
\hline 8.12 & 16.24 & 0.1189 & 0.1237 & +4.0 \\
\hline 0.0 & 0.12 & 0.0873 & 0.0935 & +6.9 \\
\hline
\end{tabular}

Fuel Element Benchmark Comparisons Using VIM and DIF3D

The modeling of the fuel elements with a single homogeneous composition was benchmarked using the detailed-geometry VIM model. Adjustments to the microscrpic thermal absorption cross section for ${ }^{10} \mathrm{~B}$ or ${ }^{149} \mathrm{Sm}$ burnable absorbers in the DIF3D model were not necessary in order to obtain good agreement with VIM. However, adjustments to $\sigma_{a_{5}}$ as a function of burnup were required when $C d$ wires were Introduced Into the LEU fuel elements because of thelr smaller burnable absorber volume.

VIM and DIF3D comparisons for fresh HEU and LEU fuel elements with $10_{B}$ and ${ }^{149} \mathrm{Sm}$ in the fuel meat are presented in Table 5. The first comparison is of the standard $400-\mathrm{g}-235 \mathrm{U}$, six-plate element loaded with $3.8 \mathrm{~g} \mathrm{~B}$ and $1.4 \mathrm{~g} \mathrm{Sm}$ in the fuel meat. The results of the DIF3D-VIM comparison indicate that for fresh fuel conditions the DIF3D reactivity is overpredicted by $\sim 0.009 \Delta k_{\infty}$ relative to VIM. ThIs bias appears to be constant during the lifetime of the fuel, based on other comparisons without the burnable absorber present. Absorption rates are modeled well enough so that predictions of fuel and burnable absorber depletion rates should be acceptable for fuel cycle calculations.

The other two comparisons given in Table 5 are for two different designs for an LEU element loaded with $480 \mathrm{~g} 235 \mathrm{~V}, 3.8 \mathrm{~g} \mathrm{~B}$, and $1.4 \mathrm{~g} \mathrm{Sm}$ in the fuel meat zone. The first LEU element design has the outer water gap between the Be matrix block and the outer fuel plate equal to all other water channels. The second LEU design preserves the same outer water gap thickness used in the reference HEU design and reduces the Inner water channel thickness from $3.00 \mathrm{mom}$ to $2.74 \mathrm{mn}$. The second LEU design has been adopted for thermal-hydraulic considerations. The DIF3D model is in slightly better agreement with the VIM model for these two LEU designs than was the case for the HEU element. The reactivity of DIF3D is $\sim 0.003 \Delta k_{\infty}$ greater than the VIM model for fresh LEU conditions. However, this bias increases to $\sim 0.010 \Delta \mathrm{k}_{\infty}$ upon complete depletion of the ${ }^{10} \mathrm{~B}$ burnable absorbers, simflar to the bias for the HEU case at end of 1ife. Since it was necessary to make burnup-dependent adjustments to $\sigma_{a_{5}}$ of $113 \mathrm{Cd}$ in the DIF3D mode1, $k_{\infty}$ differences between VIM and DIF3D are $60.005 \Delta k_{\infty}$ throughout fuel 11fetime. 
Sable 5. Benchmark Comparision of VIM and Single-Composition DIF3D Models of Fresh $400-g-235 \mathrm{U}$ HEU Reference Element and $480-\mathrm{g}-235 \mathrm{U}$ LEU Element in an Infinite Lattice Using $3.8 \mathrm{~g} \mathrm{~B}+1.4 \mathrm{~g} \mathrm{Sm} \mathrm{in}$ Fuel Meat

\begin{tabular}{|c|c|c|c|c|c|c|}
\hline \multirow[b]{2}{*}{ Ieotope } & EEU & lenent & $\begin{array}{r}\text { Letional } \\
\text { LEU }\end{array}$ & $\begin{array}{l}\text { Iorptsons } \\
\text { ment }\end{array}$ & IEV E & ent \\
\hline & ym & DIF3D & VIY & DIF3D & VIR & DIrjo \\
\hline 2050 & $\overline{0.6636}$ & 0.6671 & 0.6552 & 0.6530 & 0.6529 & 0.6551 \\
\hline $238_{0}$ & 0.0046 & 0.0047 & 0.0794 & 0.0784 & 0.0774 & 0.0780 \\
\hline${ }^{27} \mathrm{MI}$ & 0.0226 & 0.0212 & 0.0178 & 0.0172 & 0.0180 & 0.0172 \\
\hline $10_{B}$ & 0.165 & 0.1654 & 0.1325 & 0.1356 & 0.1344 & 0.1354 \\
\hline s: & - & - & 0.0007 & 0.0006 & 0.0006 & 0.0006 \\
\hline 1495 & 0.0519 & 0.0529 & 0.0424 & 0.0420 & 0.0428 & 0.0419 \\
\hline $\mathrm{B}_{2} \mathrm{O}$ & 0.0733 & 0.0700 & 0.0537 & 0.0529 & 0.0554 & 0.0547 \\
\hline 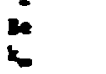 & $\begin{array}{l}0.0190 \\
1.3878\end{array}$ & $\begin{array}{l}0.0188 \\
1.3969\end{array}$ & $\begin{array}{l}0.0182 \\
1.3769\end{array}$ & $\begin{array}{l}0.0204 \\
1.3804\end{array}$ & $\begin{array}{l}0.0185 \\
1.3682\end{array}$ & $\begin{array}{l}0.0180 \\
1.3710\end{array}$ \\
\hline
\end{tabular}

EQUILIBRIUM FUEL CYCLE ANALYSES FOR CORE CONEIGURATION 1OD

Comparison of Euel Cycle Performance Characteristics

The purpose of these fuel cycle calculations was to determine the LEU fuel element design parameters required to approximate the reference UEU equilibrium fuel characteristics. The first step in this process, after benchmarking the ECELL/DIF3D model using VIM, was to determine the reference HEU fuel equilibrium cycle characteristics for core configuration 10D. This configuration is shown in Fig. 3. The fuel cycle length of 19.8 days, reload batch size of eight elements, and operating power level of $56 \mathrm{MW}$ or $67 \mathrm{MW}$ were all determined based on data supplied by the BR2 staff. Since the control rods move very little during the cycle, the average control rod position was fixed at 505 mo for all three-dimensional. fuel cycle calculations.

The results of the nodal diffusion theory hexagonal- $\mathrm{Z}$ fuel cycle calculatione performed using REBUS3 ${ }^{6}$ with burnup-dependent cross sections are presented in Table 6 for HEU or LEU fuel loaded with boron or cadmium burnable absorbers in core configuration 10D. The 12-element inner ring powers are slightly highe: than the target $26.5 \mathrm{MW}$ for operation at $56 \mathrm{MW}$ probably because no experiments have been modeled inside the inner fuel ring. The first two LEU fuel cycles were for elements with $36 \mathrm{~cd}$ wires having diameters of $0.5 \mathrm{~mm}$ and $0.4 \mathrm{~mm}$, respectively. In both cases the $\mathrm{Cd}$ has been fully depleted by the end of the second cycle of Irradiation except in the top of the core adjacent to control rods. The case using $0.4-\mathrm{mm}$ wires has a larger excess reactivity at every burnup during the cycle without large swings in reactivity during the cycle. The comparison of the LEU cycle with 0.4 min $C d$ wire, and reference HEU cycle operating at $67.2 \mathrm{MW}$, increases the reactivity advantage of this LEU cycle for higher burnups. It appears to be the best LEU fuel cycle compared to the HEU cycle. The case with $2.85 \mathrm{~g} \mathrm{~B}$ loaded into the fuel meat replacing the Cd wires is presented in the last colunn of Table 6. This case would be an alternative to the use of $C d$ wires since the reactivity performance is close to that of the HEU reference cycle. 
Figure 3. Power Produced per Element in MW, HEU Core BOEC, Control Rods at.505 mm for Core Configuration 10D

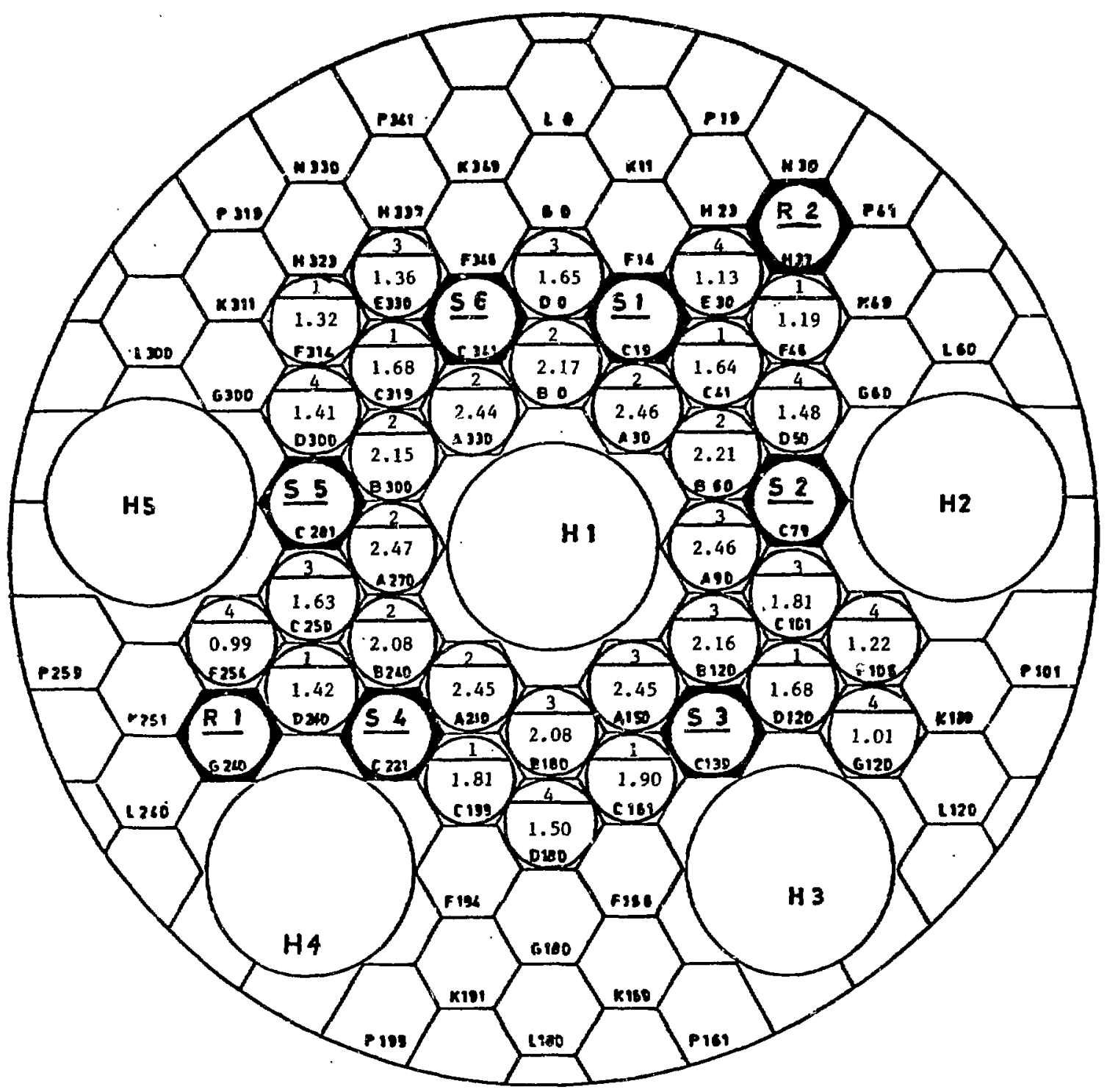

Note: Fuel batch number given at top of each element. 
Table 6. Equilibrium Fuel Cycle Characterlatics Using Be Plugs for Each Fuel. Irradiation or Reflector Postion In 31-Element Core (Configuration 10D)

\begin{tabular}{|c|c|c|c|c|c|c|}
\hline Bartehrant & aso & und & 200 & $\mathbf{m}$ & $\boldsymbol{L N}$ & 20 \\
\hline coosetry of rodel & & & Bexagonal- & $1-2-$ & & \\
\hline Contral rod position, $=$ & 505 & 305 & 505 & 505 & 505 & 505 \\
\hline Isloede/eyale & 8 & 8 & 8 & 8 & 8 & 8 \\
\hline Crele length, deye & 19.8 & 19.8 & 19.8 & 19.8 & 19.8 & 19.8 \\
\hline Core Power, Mi & 56 & 67.2 & 36 & $\mathbf{s 6}$ & 67.2 & 56 \\
\hline 2350 s/alenani & 400 & 400 & 480 & 480 & 480 & 480 \\
\hline \multicolumn{7}{|l|}{ surnable absorbar/element } \\
\hline $\begin{array}{l}\text { 8. } 3 \text { or Cd dree, } \\
(\mathrm{m}, \mathrm{D})\end{array}$ & 3.8 & 3.8 & $\begin{array}{l}36 \mathrm{Cdu} \\
(0.5)\end{array}$ & $\begin{array}{l}36 \text { cest } \\
(0.4)\end{array}$ & $\begin{array}{l}36 \mathrm{cdn} \\
(0.4)\end{array}$ & 2.85 \\
\hline $8 \mathrm{sin}, I$ & 1.4 & 1.4 & 1.4 & 1.4 & 1.4 & 1.4 \\
\hline $\begin{array}{l}k_{\text {BOEC }} \\
k_{15 O E C} \\
k_{E O E C}\end{array}$ & $\begin{array}{l}1.1470 \\
1.1407 \\
1.1339\end{array}$ & $\begin{array}{ll}90 & 1.1375 \\
07 & 1.1272 \\
39 & 1.1085\end{array}$ & $\begin{array}{ll}5 & 1.1332 \\
2 & 1.1245 \\
5 & 1.1223\end{array}$ & $\begin{array}{ll}2 & 1.1580 \\
5 & 1.1439 \\
3 & 1.1364\end{array}$ & $\begin{array}{ll}10 & 1.1536 \\
19 & 1.1326 \\
1 & 1.1200\end{array}$ & $\begin{array}{ll}6 & 1.1610 \\
4 & 1.1423 \\
0 & 1.1365\end{array}$ \\
\hline Inner Ring Power, w & 27.6 & 34.1 & 26.8 & 26.9 & 33.0 & 26.9 \\
\hline 2350 loading, s0EC, h8 & 10.24 & 9.76 & 12.81 & 12.83 & 12.39 & 12.80 \\
\hline EOEC, $\mathrm{kg}$ & 8.84 & 8.08 & 11.46 & 11.48 . & 10.77 & 11.44 \\
\hline \multicolumn{7}{|l|}{$\begin{array}{l}\text { Burnable Absorleer } \\
\text { ECSC Burnup }(X)\end{array}$} \\
\hline Batch 1 & 45.2 & 52.6 & 55.7 & 67.0 & 76.1 & 38.8 \\
\hline Batch 2 & 76.6 & 83.7 & 89.7 & 94.0 & 96.8 & 69.0 \\
\hline Bateh 3 & 87.9 & 92.3 & 95.7 & 98.2 & 99.3 & 82.1 \\
\hline Batch 4 & 92.0 & 94.9 & 97.8 & 99.4 & 99.8 & 87.5 \\
\hline \multicolumn{7}{|l|}{ Power Peak1ng $\left(W / \mathrm{en}^{3}\right)$} \\
\hline BOEC & 977 & 2184 & 965 & 966 & 2182 & 987 \\
\hline MOEC & 938 & 1133 & 975 & 970 & 1151 & 960 \\
\hline EOEC & 894 & 1040 & 944 & 915 & 1064 & 928 \\
\hline
\end{tabular}

Neutron Flux Changes in LEU Relative to HEU Cores

The changes in the neutron energy spectrum in LEU cores relative to identical fuel management HEU cores are caused by increased ${ }^{235} \mathrm{U}$ and ${ }^{238} \mathrm{U}$ content as well as by replacement of $10_{\mathrm{B}}$ burnable absorbers with Cd wires. The increased $U$ density in $L E U$ fuels tends to harden the neutron spectrum, partlcularly in the fuel zones of the core. This harder spectrum increases the core neutron leakage such that fluxes in the reflector and peripheral fuel elements may actualiy increase in LEU cores. Fast neutron fluxes above $1.8 \mathrm{eV}$ in LEU cores remain close to HEU fast fluxes because the fast neutron source is unchanged for cores producting the same power. Thermal neutron fluxes in LEU cores are usually 20 to $30 \%$ below HEU fluxes in the fuel elements, but reductions of only 5 to $10 \%$ are usually observed in irradiation positions. The thermal neutron flux reduction is usually lower in non-fuel positions because their primary neutron source, the fast neutron leakage into them from adjacent fuel elements, has not changed. 
Shown In FIgs. 4 and 5 are plots of element-average BOEC neutron flux rat1os for LEU relative to HEU cores. The LEU core consisted of elements with $36 \mathrm{Cd}$ wires ( $0.4 \mathrm{~m}$ OD) for burnable absorbers. All comparisons were performed using configuration 10D with all rods fixed at $505 \mathrm{~mm}$. The standard five broad energy group boundaries were used to show the energy distribution of the neutron flux. The plot In Fig. 4 shows how the flux ratio changes in moving across the core from reflector position 2000 to the opposite edge of the core In position L180. Similarly, Fig. 5 shows how the flux ratio changes in moving at a slightly different angle across the core from L300 to L120. The fluxes in LEU core reflector positions are slightly higher than for equivalent-fuel-management HEU cores. Fast flux ratlos are usually greater than untty and are also dependent on redistributions of power from HEU to LEU cores.

These plots are only representative in an average sense of the neutron flux changes in the core and provide only limited information about changes within a given element. VIM results have shown reductions in thermal flux of 15 to $20 \%$ In the central plug zone of fresh fuel elements while fast flux changes follow trends presented for average element fluxes. The Be central plug of each fuel element should be replaced with an experiment in order to obtain more realistic thermal flux changes in the. plug zone.

\section{Excess Reactivity Calculations}

The control rods were withdrawn so that only the Be follower was present in-core in order to determine the excess reactivity at BOEC and EOEC for HEU relative to LEU fuel cycles operating at $56 \mathrm{MW}$. The BOEC and EOEC cases for HEU and LEU fuel cycles in hexagonal-Z geometry with all control rods flxed at 505 $\mathrm{mm}$ were used tor the reference cases. After control rod withfrawal the reactivity of the HEU core increased $3035 \mathrm{pcm}$ and $3183 \mathrm{pcm}$ for BOEC and EOEC conditions, respectively. Similarly for the LEU core using 36 Cd wires (0.4 m OD), the reactivity increased $3303 \mathrm{pcm}$ and $3269 \mathrm{pcm}$ for BOEC and EOEC conditions, respectively.

These results are not control rod worths since the rods were not withdrawn from their critical rod positions. However, they are indications of relative control worth since the $k_{\text {eff's }} s$ are nearly equivalent for both HEU and LEU fuel cycles before withdrawal of the rods. The burnable absorber content has a strong Influence upon excess reactivity. Since $50 \%$ of the LEU fuel elements contain no burnable absorber, more neutrons are captured in the control rods in the LEU case. This accounts for slightly more excess reactivity and control rod worth in the $L E U$ core relative to HEU.

\section{CONCLUSIONS}

Preliminary fuel cycle analyses using HEU and a few possible LEU fuel elements have been completed. 1t appears that there 18 a small incentive to use 0.4-mm-OD Cd wire burnable absorber compared to boron mixed into the fuel meat. A slight improvement in the reactivity performance is predicted and power peaking has been reduced by $\sim 5 \%$, when credit is taken for local power reductions within the element. The use of $25 \%$ less boron burnable absorber materlal $(2.85 \mathrm{~g})$ Instead of Cd wires and $20 \%$ more ${ }^{235} \mathrm{U}$ provides an LEU fuel cycle very simflar to the reference HEU cycle. In order to increase the ${ }^{23} \mathrm{U}$ content to 
Ratio of LEU to HEU FluX

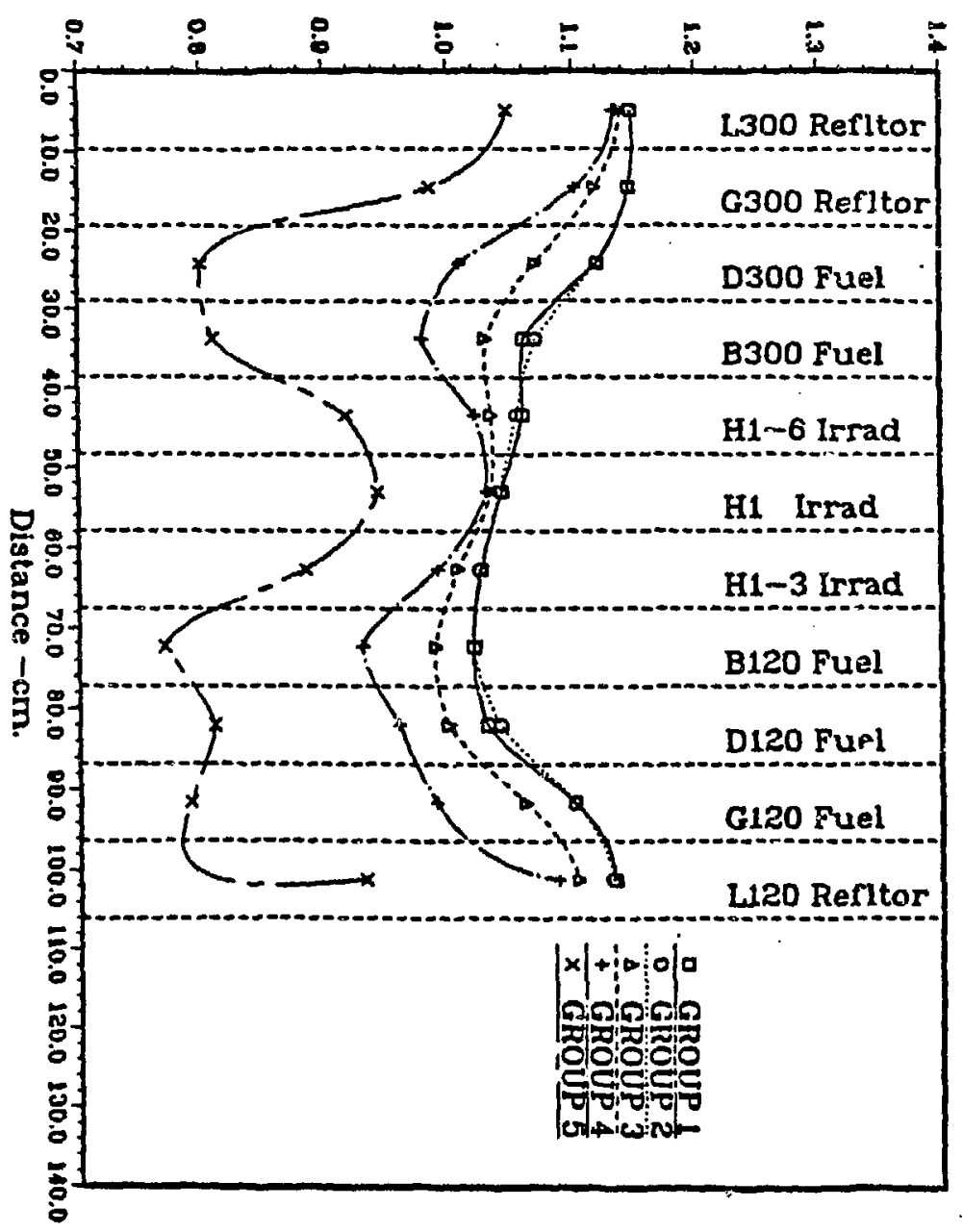

Ratio of LEU to HEU Flux

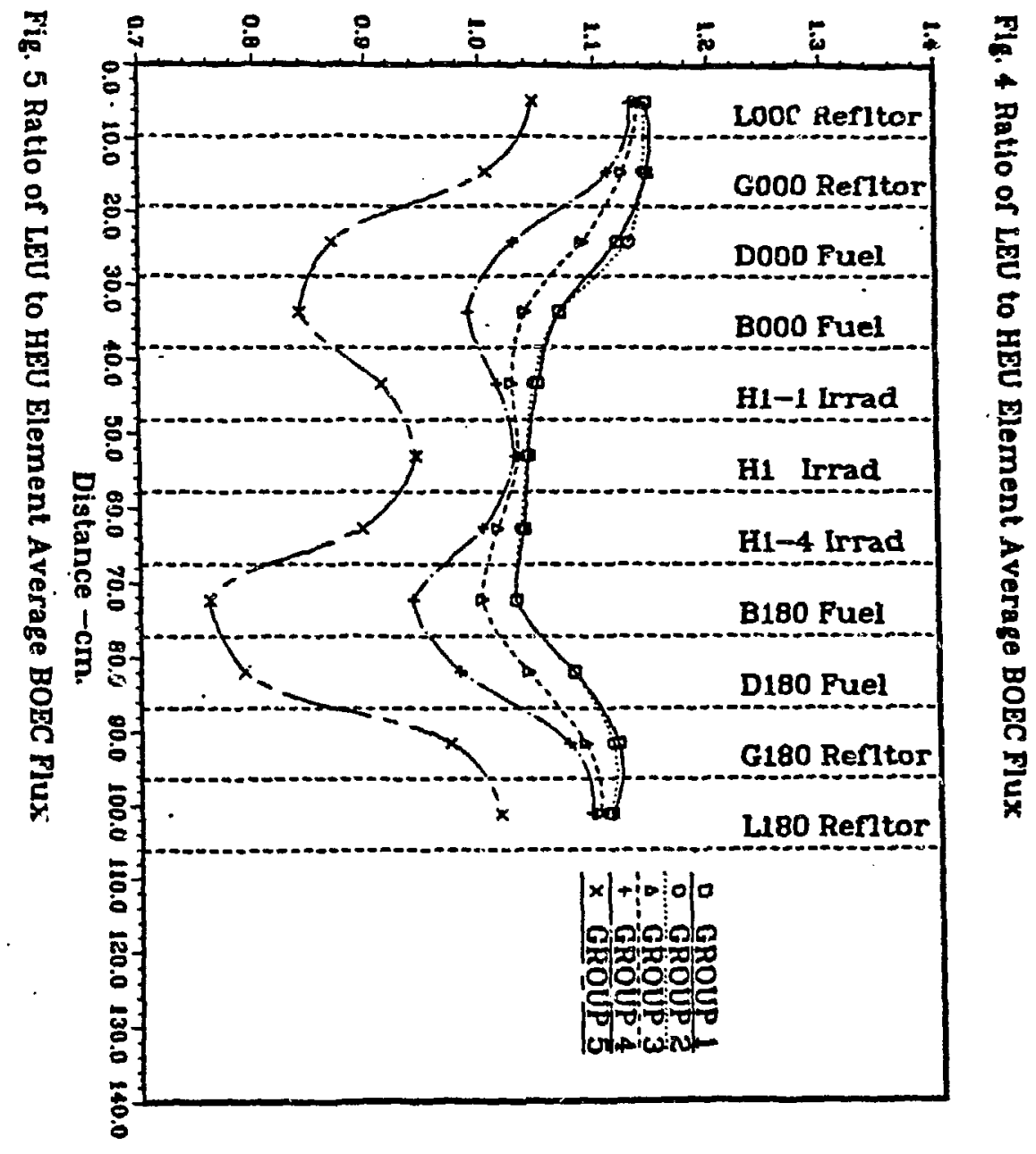


$480 \mathrm{~g}$, the required uranium meat density for the LEU cycle ranges from 4.92 to $5.14 \mathrm{M} \mathrm{g} / \mathrm{m}^{3}$, depending on cholce of burnable absorber. Control rod worths are not significantly affected by the change from HEU to LEU fuel due to the change from boron to faster depleting Cd burnable absorbers. Epithermal neutron flures are slightly higher in LEU relative to HEU cores while thermal neutron losses are $<10 \%$ in non-fueled positions. Addition of materials to model actual experiments would provide more accurate power distribution and reactivity information but would not be expected to change the conclusions of these comparative HEU/LEU fuel cycie analyses.

\section{REF ERENCES}

1. J. M. Baugnet, et. al., "The BR2 Materıals Testing Reactor and the RERTR Program, Present Status and Future Trends," Proceedings of the 1984 International Meeting on Reduced Enrichment for Research and Test Reactors, Argonne, Il11no1s, October 15-18, 1984, RERTR-TM-6, CONF-8410173, p.423-445 (July 1985).

2. "VIM-A Continuous Energy Monte Carlo Code at ANL," A Review of the Theory and Application of Monte Carlo Methods, Proceedings of the SeminarWorkshop, ORNL/RSIC-44, Apr11 21-23, 1980.

3. A. Beeckmans, "Summary of Studies Carried Out for the Definition of the Maximum Allowed Heat Flux In the BR2. Reactor," these proceedings.

4. B. A. Zolotar, et. al. "EPRI-CELl Descrlption, "Advanced Recycle Methodolog) Program System Dorumentation, Part II, Chapter 5, Electric Power Researcn Institute (September 1977). EPRI-CEJ.L code supplied to Argonne National Laboratory by Electric Power Research Institute, Palo Alto, Callfornia (1977).

5. K. L. Derstine, "DIF 3D: A Code to Solve One, Two, and Three Dimensional Finite Difference Diffusion Theory Problems," ANL-82-64 (April 1984).

6. B. J. Toppe1, "A User's Guide for the REBUS-3 Fuel Cycle Analysis Capability," ANL-83-2 (March 1983). 